\title{
Central Margins: Paradox and Transformation of Dichotomies in Two English Language Novels by Mauritian Lindsey Collen
}

\author{
Nancy Elaine Wright \\ Pace University
}

\begin{abstract}
The Indian Ocean region embodies the paradox of a marginalized crossroads. Its islands and coastal societies reflect the multiple influences of its position as a commercial center during colonization and accompanying slave trade. Yet its island nations, particularly their literature, are little known relative to their mainland Asian and African counterparts. Mauritius further reflects these ironies. Although Mauritius has attained a positive reputation for stability, growth, and tourist appeal, deep inequalities resulting from economic globalization persist, to the detriment of its citizens. Uninhabited until the arrival of the Dutch in the sixteenth century, its national identity is the most multicultural of the Indian Ocean islands. Despite its history as a British colony and the designation of English as the language of school instruction and government administration, English-language Mauritian literature remains scarce. A primary exception is the work of novelist Lindsey Collen. This paper examines Collen's There Is a Tide and The Rape of Sita as examples that reveal margin and center as imagined divisions, created by patriarchal assumptions about power and humans' relationship to the earth. Theories of hybridity and postcolonialism, as well as of feminism, eco-feminism, and ecocriticism, introduced to challenge these assumptions, have revealed both deeply intertwined concepts and continuing problems of cultural domination, despite efforts to counter legacies of colonial injustices. The reactive nature of many of these theories and the advocacy on which they are based ironically often reinforce the aforementioned dichotomies between center and margins. Collen's novels deconstruct and transform these dichotomies by narrating the human condition across gender, class, nation, and time in ways that are difficult (if not impossible) to do through theoretical categorization.
\end{abstract}

(C) Nancy Elaine Wright. This is an Open Access article distributed under the terms of the Creative Commons License CC BY NC SA, which permits users to share, use, and remix the material provided they give proper attribution, the use is noncommercial, and any remixes/transformations of the work are shared under the same license as the original. 


\section{INTRODUCTION}

The Indian Ocean region embodies the paradox of a marginalized crossroads. Its islands and coastal societies reflect the multiple African, Asian, and European influences and its position as a commercial hub during the age of colonization and accompanying slave trade. Yet, with the possible exception of Madagascar, its island nations are little known; moreover, its literature is little known compared to that of its mainland Asian and African counterparts. African literature scholar Moradewun Adejunmobi attributes this largely to what he terms the "apparent reluctance" of Indian Ocean writers to anchor their political activism in regional unity, and the proximity of the Indian Ocean islands to the African continent and related collective memories of slavery. ${ }^{1}$

This article examines two novels by Mauritian writer Lindsey Collen, with a view to illustrating how her writing exemplifies margins at the center, through her choice to write in English and her complex tapestry of postcolonial - including hybridization, creolization, and cosmopolitanism - feminist, ecofeminist, and ecocritical perspectives, which usher the historically marginalized to the forefront. The novels are There Is a Tide, ${ }^{2}$ her first novel, and The Rape of Sita, ${ }^{3}$ for which she became and has remained most renowned. The article makes two principal arguments. First, by writing and publishing the novels in English, considered the secondary colonial language of Mauritius, but also featuring as main characters pre-literate and speakers of Kreol, Collen both brings the marginalized peoples of Mauritius to the forefront and introduces them to readers who otherwise would not likely know of them or Mauritius' legacy. Second, by representing in her novels key concepts and arguments of postcolonialism, feminism, ecofeminism, and ecocriticism, Collen presents the complexities and intricacies of these theories that have spawned much disaggregation and critique, including criticisms of ambiguity and lack of rigor, particularly with respect to the latter three. This article shows through Collen's work that these criticisms oversimplify the theories themselves; as theories that have been developed from the empiricism of observation and experience, they cannot be reduced to the precision that critics advocate, for to do so would diminish the integrity and accuracy of what they represent, just as oversimplifying Mauritius' economic growth and sociopolitical evolution misrepresents the total reality of those who inhabit the island.

\footnotetext{
${ }^{1}$ Moradewun Adejunmobi, "Claiming the field: Africa and the space of the Indian Ocean literature," Callaloo: A journal of African diaspora arts and letters, 32, 4 (2009), 1247-61.

${ }^{2}$ Lindsey Collen, There Is a Tide (Port Louis: Ledikasyon pu Travayer, 1990).

${ }^{3}$ Lindsey Collen, The Rape of Sita (Port Louis: Ledikasyon pu Travayer 1993).
} 
Mauritius has been identified as the geographical and intellectual center of the Indian Ocean since the 1960s, with a long tradition of Indian Ocean studies (see, for example, Mauritian Auguste Toussaint's seminal History of the Indian Ocean). ${ }^{4}$ Folklore scholar Lee Haring drew inspiration for his book, Stars and Keys: Folktales and Creolization in the Indian Ocean from Mauritius, explaining, "On the seas, Mauritius is a starlike point for navigation, the nation sees itself as a key to the important wealth-giving trade routes between the East Indies and Europe." More recent concerns with climate change and other crises associated with the Anthropocene have beckoned scholars to delve more deeply into the region's history and culture in a way that transcends national borders. A key example of this is a phenomenon that Isabel Hofmeyr identifies as "hydrocolonialism," which embodies a colonial and post-colonial view of worlds of water. ${ }^{6}$ According to hydrocolonialism, literature is demarcated less by specific nations and more by bodies of water and phenomena such as hurricanes, cyclones, tidal waves, and monsoons.

Called both the "Mauritian Miracle" and "The African Tiger," Mauritius received substantial foreign investment after the third International Monetary Fund (IMF) restructuring program in 1980 and the first structural adjustment loan from the World Bank in $1981 .^{7}$ Through her novels, Collen sharply critiques this portrait, revealing the negative by-products of this seemingly beneficial growth, from those who bore the cost through slavery and indenture of Mauritius' evolution to nationhood, to the sweatshop and other labor that formed the backbone of the island's transition from an agrarian sugarcane economy to greater economic diversity, including textiles. ${ }^{8}$

For Collen, the Indian Ocean is thus a metaphor for the paradox of Mauritius. Recalling her journey to the Seychelles, she has noted how the stunning beauty from the surface masks the undertow, an ongoing rip current of persistent poverty underlying an economy historically base on plantation agriculture and in recent decades dominated by elite tourism. The Indian Ocean also marks the route of transport of slaves to the islands, a legacy in stark juxtaposition to the waterway as an inviting route for cruise ships. ${ }^{9}$ In Rachel Matteau Matsha's and Lindy Stiebel's words:

\footnotetext{
${ }^{4}$ Auguste Toussaint, History of the Indian Ocean (London: Routledge, 1966).

${ }^{5}$ Lee Haring, Stars and Keys: Folktales and Creolization in the Indian Ocean, trans. Claudie Ricaud and Dawood Auleear (Bloomington: Indiana University Press, 2007).

${ }^{6}$ Isabel Hofmeyr, "Literary ecologies of the Indian Ocean," English Studies in Africa, 62, 1 (2019), 1-7.

${ }^{7}$ Felicity Hand, 'Lindsey Collen: The courage to be parochial," Wasafari, 26, 2 (2011), 42.

${ }^{8}$ Ibid., 42.

${ }^{9}$ Rachel Matteau Matsha and Lindy Stiebel, "Deep sea writing: Recent conversations with Lindsey Collen, writer and activist from Mauritius," Journal of the Indian Ocean Region, 13, 3 (2017), 331.
} 
Behind and below the illusion of the stereotypical welcoming and beautiful Indian Ocean and its islands, Collen's point was that there is the deep surface of historical lived experiences involving those same waters, filled with diasporic and displaced pain extending back over years. ${ }^{10}$

In addition to harboring persistent socioeconomic disparities, Mauritian society is highly patriarchal. Ramola Ramtohul points to the discrepancy between the legal framework of ostensible equality for women and the reality that social norms impose, a juxtaposition not unlike the aforementioned contradiction between the "Mauritian miracle" and daily life for much of the populace. Through presentation of her research findings, Ramtohul illustrates that the major emphasis attributed to ethnic and communal representation in Mauritian politics ironically marginalizes women's political citizenship. This phenomenon results from the frequent sponsorship of political candidates by maledominated religious and sociocultural organizations, in which women's efficacy is weak in comparison to communal influence. Furthering this paradox is the extreme resistance of this gendered communalism to change, thus perpetuating the marginalization of women. ${ }^{11}$

This article proceeds as follows: First, it identifies key themes and characteristics in There Is a Tide and The Rape of Sita, along with a description of the storytelling and folkloric aspects of the novels. Second, it illustrates how Collen's novels, situated within the Indian Ocean's literary and historical context, bring Mauritius and English language writing of the region from the margins to the forefront, and in so doing expose the false dichotomy between marginalized and central, much as Mauritius bears the dual legacy of a maritime commercial hub and tourist paradise and a place of great suffering and resilience. Third is a discussion of the relationship of Collen's novels to theories of hybridity, cultural negation, postcolonialism, cosmopolitanism, and creolization. The fourth section addresses Collen's novels in relation to theories of feminism, eco-feminism, and eco-criticism. The paper then summarizes the aforementioned statements and draws some conclusions about the way in which Collen's work illustrates the role of literature in the complexity of the theories addressed herein, by bringing not only marginalized populations, but also marginalized concepts, to the forefront and by reinforcing the difficulty and risk of excessive deconstruction of these related theories.

\footnotetext{
${ }^{10}$ Ibid., 331.

${ }^{11}$ Ramola Ramtohul, “Intersectionality and women's political citizenship: The case of Mauritius," Journal of Contemporary African Studies, 33, 1 (2015), 27-47.
} 


\section{There is a TIDE ANd The RaPe of Sita: Key Themes And Characteristics}

Within the realm of Indian Ocean literature, Collen's two novels are distinguished by their storytelling approach, their incorporation of folklore and mythology, and the fact that they are written in English. Noting the threat of globalization to national languages that are not those of the colonizers, "world-wide vehicular languages... which carry with them a considerable postcolonial baggage," Peter Hawkins highlights Collen as an example of a writer "no longer identifiable simply within a national culture, even if that is one of their major formative influences." 12 To elaborate, Collen came of age as a privileged Anglophone in South Africa, but with an early and firmly rooted commitment to social justice, focused at the time on resistance to apartheid. Writing in English has granted her access to major publishers and a wider reading audience - certainly far greater than if she had written primarily in Kreol-yet the focus of her novels is the social tensions and contradictions of Mauritian society that are often overlooked by those who uphold Mauritius as a model of democratic stability and steady economic growth. Moreover, although both of the novels discussed herein are written in English, they represent the voices of those largely Kreol-speaking, pre-literate Mauritians who have little voice in their own lives or destinies, hence her extensive use of interior monologue. ${ }^{13}$

There Is a Tide contains three interconnected narratives: One is by Fatma, the midwife, the second by Shynee, a machinist at a shirt factory who conducts an in-depth self-analysis and reflection on her refusal to eat, and the third by a psychotherapist who epitomizes the best of middle-class professional Mauritian life as imagined by outsiders, but ultimately occupies the same prison that Shynee's father Larmwar had occupied for his labor activism - all ensconced within a foreword written in the year 2051 by a reporter named Jaya Ng Sang. A second foreword, whose authorship is implicitly Collen herself, describes an encounter in 1991 with a book by Koko Bi Panchoo, also titled There Is $A$ Tide with a publication date 60 years later. Upon learning that bookstores refuse to stock copies, given that it is not yet published, the author decides to publish it herself. The heroes are the working-class Shynee and Fatma whose continued resistance to capitalism portend a more just future for all Mauritians and quite possibly for all people worldwide. The novel upholds the multicultural nature of Mauritius as the key to this better society. Again, an

\footnotetext{
${ }^{12}$ Peter Hawkins, "Until when shall we remain postcolonial? Globalization, nationalism, and cultural self-determination in the literatures of the Indian Ocean," E-France: An on-line journal of French studies, 2 (2008), 10.

${ }^{13}$ Stephen Gray, "The daring fictions of bilingual Lindsey Collen," English in Africa, 42, 2 (2015), 131-2.
} 
ironic element emerges: this multiculturalism becomes a hallmark of tourism for Mauritius, but with a view to drawing visitors to its natural beauty and cosmopolitan forms of hybridity (such as those noted by Hawkins), rather than to improving the lives of the working class. Yet, writing in English but having the protagonists not as members of such an elite, calls English-speaking outsiders to reappraise their idyllic visions of the island in a way that they would not likely understand, were the novels written in Kreol.

The Rape of Sita is the story of a political activist named Sita, who is on her way to serve as a delegate for a women's movement conference in the Seychelles. In order to be back in Mauritius for May Day celebrations, she returns via Réunion, where she contacts Rowan and Noella Tarquin, the only people she knows there. Upon her arrival at their home, she learns that Noella has left Rowan, who resents Sita's assertiveness and rapes her. Sita buries the memory of her rape for eight years. The narrative of her recalling the crime is told by a rather androgynous narrator named Iqbal, whose listening audience constantly interrupts him with corrections and modifications. Similar to There Is a Tide, The Rape of Sita contains two outer frame narratives: One is the preface, which informs the reader that the novel will reveal all the things Iqbal's publisher has forbidden, such as directly addressing the reader and accommodating digressions, and a poem written by Time personified, which appears before the novel begins.

Both folklore and myth figure prominently in the two novels, something which again brings the marginalized to the center. Lee Haring has stressed the importance of folklore in synthesizing elements of many disciplines and achieving authenticity through hybridity. ${ }^{14}$ Because folktales are disseminated, relayed, remembered, and duplicated by rank and file people, the reader has no choice but to depend on multiple means of communication, including oral tradition, transcription, and translation, as well as imagination. ${ }^{15}$ Myth draws upon history, but also transcends it and thereby exposes the limits of what one normally identifies as a historical perspective. Myth reveals that all history is perspective. ${ }^{16}$

The protagonist in The Rape of Sita is the namesake of the central female character in the Hindu epic myth, Ramayana; she is worshipped as the incarnation of Lakshmi, the consort of Vishnu, who protects the earth from destruction. Soon after the book was first released on December 3, 1993, the novel was banned among Hindu fundamentalists for

\footnotetext{
${ }^{14}$ Lee Haring, "Roger Abrahams, creolization, folklore theory," Western Folklore, 75, 3-4 (2016), 287.

${ }^{15}$ Lee Haring, "One evening in Mayotte," Marvels and Tales, 23, 1 (2018), 76.

${ }^{16}$ See: Natalie Gilman, “'A bunch of grapes': A reading of Lindsey Collen's The Rape of Sita” (Unpublished M.A. Thesis: University of Pretoria, 2006).
} 
blasphemy, for Sita in the novel becomes clearly an agent rather than a subject or object of her destiny. The African Literature Association's Bulletin, Volume 20, Number 2, Summer 1994 issue reported that Collen had been threatened with public rape when the book was first released in 1993. In response, she and her local publisher withdrew the novel from circulation. Subsequently, the international Writers in Prison Committee called for a complete investigation of the threats, describing Collen as "a leading member of LALIT, a political group working on trade union, squatters' and women's rights," not unlike Sita, the novel's protagonist and heroine. The following issue of the Bulletin lauded the novel and reproduced the Commonwealth Writers Prize jury's evaluation which explained why it had been awarded the prize in 1994 for the best book from Africa. ${ }^{17}$

Rowan Tarquin, the name of the rapist, is a combination of the rapist Tarquin from William Shakespeare's The Rape of Lucrece and Rowan, a modification of the name Ravana, the multi-headed demon king of Lanka in Hindu mythology. The fact that Sita begins the journey of recalling the rape on the same day that the United States invaded Iraq assigns a more universal - and of course controversial - meaning to the story and its characters.

Related to myth and folklore is the art of storytelling, which is the approach in both novels. Collen has identified a necessary relationship between storyteller and reader/listener, such that there is an exchange throughout. In fact, Collen's writing evolved from her prior work as a storyteller for the women's movement in Mauritius. Although the fact that the novels are in English offers an advantage in terms of an accessible and salable commodity, Collen views the relationship between writer and reader through storytelling as something dynamic and reciprocal that far transcends commodification. Thus again, the paradox emerges of work written in English, a language associated with the former colonizer and accessible to a more global market, but written in a style that both gives voice to descendants of the colonized and summons the readers - who understand the colonizers' English - to engage actively in the narrative. ${ }^{18}$

The style of storytelling in The Rape of Sita contributes to the universality of oppression and hope for transformation. As Felicity Hand explains:

The discursive strategy which frames Iqbal's narrative of the circumstances leading up to and following in the wake of the rape of Sita draws from

\footnotetext{
${ }^{17}$ Gray, "The daring fictions," 135.

${ }^{18}$ Helen Cousins, "Lindsey Collen's narrative gift: A challenge to the commodification of African literature," Research in African Literatures, 49, 2, (2018), 91.
} 
traditional Mauritian folklore and storytelling. Iqbal begins his tale with the cry of siraddann (can I tell you a story?) to which his listeners must answer if interested sanpek (go ahead). This inscribing of the novel within the Mauritian tradition gives voice to the mixture of cultural traditions, typical of plantation societies, where people from diverse ethnic backgrounds kept their spirits up - and evaded feelings of uprootedness and alienation-by recounting folk tales. ${ }^{19}$

Multiculturalism is exemplified in that Iqbal, the narrator who defies publishers' admonitions of not allowing interruption by insisting on such interruption, is a Muslim narrating the rape of a Hindu woman; moreover, his empathy with Sita imparts a blurring of gender. Iqbal's reference to the novel as "a bunch of grapes," ${ }^{20}$ meaning many perspectives and micro-narratives within this overall narrative, signifies further inclusiveness in a story of and by a larger humanity than the literate and literary elite. Thus, cultural, literary, and gender ambiguity all contribute to a universality in progress of a more just and equitable world where the notions of margins and center have no meaning.

\section{Lindsey Collen's Novels in the Context OF THE English Language IN Mauritian Literature}

Writing in 1980, Michel Fabre noted that English was the language of state examinations and official administrative documents and other material in Mauritius, but rarely used in daily life. At the time, French remained the language of choice in literature, due to its association with prestige and Parisian sophistication. ${ }^{21}$ Most Mauritian writers who chose to write in English did so because they considered themselves more fluent in English, and/or they wished to dissociate from the French-dominated planter elite and large business. Furthermore, their choice not to write in Kreol or another Mauritian language such as Bhojpuri was pragmatic; for example, the latter was very difficult to transliterate. Fabre identifies Anand Mullo's Watch Them Go Down as the "first truly accomplished Mauritian novel in English,"22 based on events in the 1930s history of the labor movement,

\footnotetext{
${ }^{19}$ Felicity Hand, The Subversion of Class and Gender Roles in the Novels of Lindsey Collen (Lewiston: Edwin Mellen Press, 2010), 81.

${ }^{20}$ Collen, The Rape of Sita, 5.

${ }^{21}$ Michel Fabre, "Mauritian voices: A panorama of contemporary creative writing in English," World Literature Written in English, 19, 2 (1980), 121, 123.

${ }^{22}$ Ibid., 128.
} 
especially among Indian cane laborers. Years later, That Others Might Live, by Deepchand Beeharry, portrayed the lives of Indian workers imported to Mauritius in the 1860s, and Dayachand Nepal's The Years of Tribulation also gained status in the region. ${ }^{23}$ Azize Asgarally, whom Fabre has designated "undoubtedly the most important Mauritian writer in English" wrote Man in Hiding, set in postwar Germany in a case of mistaken identity. ${ }^{24}$ Nearly two decades later, at the invitation and with the support of the British Council in Mauritius, Ron Butlin edited a volume also titled Mauritian Voices with the subtitle New Writing in English, which contains "Sacrifice," a short story by Collen. ${ }^{25}$

Writing a generation after the publication of Butlin's Mauritian Voices, Hand underscored the continuing lack of interest in developing further critical studies in the English-speaking world on Mauritian literature or Indian Ocean literature more generally. She noted that one positive outcome of the extreme controversy that ensued over The Rape of Sita was the recognition of the potential for English to be counted as a relevant language of literature in Mauritius. ${ }^{26}$

\section{Hybridity, Cultural Negation, Post-Colonialism, Postcolonialism, AND COSMOPOLITANISM: RECOGNIZING AND IDENTIFYING TRADITIONS AND Truths Through Fiction}

In addition to the ongoing disunity and the recent increased focus on water worlds and societies among Indian Ocean writers, hybridity plays a major role in Indian Ocean literature and other dimensions of culture. Vanessa Guignery has identified hybridity as "an alternative discourse that subverts the very idea of a dominant culture and a unique canon, and invites a re-examination of 'power structures'."27 Peter Hawkins, who has examined the region with a view to determining the extent to which hybridity has prompted and nurtured a distinctive regional culture apart from the elements that comprise it, stresses that, because Mauritius was uninhabited until the Dutch arrived in the late sixteenth century, it cannot claim a pre-colonial culture of its own. The society is therefore fragmented, with groups of different ethnic and religious identities competing for influence. He acknowledges that, despite this fragmentation, the Mauritian literary field is both credible and functional, then notes yet another ironic twist. The Francophone

\footnotetext{
${ }^{23}$ Ibid., 129-130.

${ }^{24}$ Ibid., 132.

${ }^{25}$ Ron Butlin (ed.), Mauritian Voices: New writing in English (Newcastle upon Tyne: Flambard Press, 1997).

${ }^{26}$ Felicity Hand, "Lindsey Collen," 41.

${ }^{27}$ Vanessa Guignery, Catherin Pesso-Miquel, and François Specq (eds.), Hybridity: Forms and Figures in Literature and the Visual Arts (Newcastle upon Tyne: Cambridge Scholars Publishing), 4.
} 
journal Notre Librairie includes Mauritian writing, not only in French, but also in Kreol, Hindi, and Chinese, as well as English. Notre Librairie, however, is not only French, but funded by the French government, which promotes Francophone literature and culture. Thus, "the very diversity of the cultural output of Mauritius is sanctioned and endorsed through one of the oldest of its colonial ties, with French metropolitan culture."28

Instead of hybridity, Ronit Frankel prefers to focus on what she identifies as cultural negation in Indian Ocean literature, which "highlights how the classificatory body of culture is generally structured in relation to its negation, its inverse." ${ }^{29}$ While hybridity challenges the concept of a dominant and a subordinate culture, cultural negation reappraises the deep roots of the culture subordinated.

Frenkel also underscores the significance of Collen's inclusion of India, along with Britain and the United States, to form a triangulation of empire, in which the characters in The Rape of Sita and their societal context create a microcosm of subjugated peoples more generally. This representation becomes evident when Sita's first recollection of her suppressed memory of rape occurs on the very day that the United States invades Iraq. Thus, Britain represents the historical colonizer, the United States represents the contemporary global and hegemonic superpower, and India represents the historical internal colonizer whose legacy is still present in the dominant Indian population of Mauritius. ${ }^{30}$ Markus Arnold confronts the related problem of postcolonial by distinguishing between post-colonial and postcolonial. The former is fixed in its definition; the latter is fluid and changing, by virtue of its locus at the crossroads of different theoretical perspectives. (For this reason, this author uses "postcolonial" throughout, as it is more congruent with the themes and concepts of the article). Accordingly, Arnold describes Mauritian literature as:

Unmistakably influenced by legacies and currents as different as anticolonial movements, vernacular modes of expression, poststructuralist patterns or postmodern thought. It relates to the local and the global, embraces the particular and the cosmopolitan, is shaped by the ideas of routes

\footnotetext{
${ }^{28}$ Peter Hawkins, The Other Hybrid Archipelago: Introduction to the literatures and cultures of the Francophone Indian Ocean (Lanham: Lexington Books, 2007), 112, 131.

${ }^{29}$ Ronit Frenkel, “A history of cultural negation in Indian Ocean literature: Julia Blackburn's The Book of Colour and Lindsey Collen's The Rape of Sita," in Eyes Across the Water: Navigating the Indian Ocean, eds. Pamila Gupta, Isabel Hofmeyr, and Michael Pearson (Pretoria: UNISA Press Indian Ocean Series, 2010), 1. Thank you to Prof. Ronit Frenkel for sharing a digital pre-print of her chapter with me. All page references are to the preprint.

${ }^{30}$ Ibid., 11.
} 
and roots..., engages into formal play as well as political commitment. More generally, it unveils shifting solidarities and various reference frames (France, Britain, Africa, India, China) to assert its multiple and processual identities. $^{31}$

Echoing Bill Ashcroft, Arnold describes the fluidity of postcolonialism as a "rhizomatic interplay of pursuits," and identifies both the nonlinear structure and plurality to characterize Mauritian novels. He further cites Roland Barthes' distinction between the ecrivant (scribe) and ecrivain (writer); the former records what is present, and the latter seeks new significance in what is present. ${ }^{32}$ As for Collen's novels:

Through their multiple commitments for gender and racial identities, their complex representations of history and present as well as their elaborated, often hybrid, style and esthetics, these texts reflect a truly emancipated postcolonial position. But one can also frequently observe militant feminist and (neo) Marxist didactics in them which clearly show that the author cannot be counted among the cosmopolitan postmodern postcolonialists. ${ }^{33}$

If, as Arnold contends, Collen's work does not fit in the category of cosmopolitan, postmodern postcolonialists, because of what he calls the "militant" feminist and neoMarxist elements in her work, this is more a reflection of the reality of theoretical fragmentation than of Collen's position in the field of literary theory. Arnold's assertion also points to the difficulty of endowing pre-literate characters, as is the case with many of Collen's novels, including the two discussed herein, with cosmopolitan attributes.

Yet another question that Arnold's discourse on cosmopolitanism raises is, to what extent is cosmopolitanism unavoidably non-universal, precisely because the source of its definition cannot be universal? An example on which Françoise Vergès elaborates is that of Creole cosmopolitanism. Vergès defines "Creole" as referring to "the identities created in the Creole societies of the French colonial empire-Martinique, Guadeloupe, Réunion

\footnotetext{
${ }^{31}$ Markus Arnold, "Between post-colonial and postcolonial: Mauritian fiction as a paradigm for literary postcoloniality in 'different degrees,," in Postcoloniality, Globalization, and Diaspora: What's next?, ed. Ashmita Khasnabish (Lanham: Lexington Books, 2020), 54.

32 Ibid., 53-4.

${ }^{33}$ Ibid., 61. Emphasis in the original.
} 
Island-slave societies, colonies of France and, since 1946, French overseas departments" 34 :

'Cosmpolitanism,' a term which has reappeared in recent years to describe an alternative way of being-in-the-world that challenges national identity, is taken here to describe the politics of Creole intellectuals who, whether during colonial times or in our current postcolonial times, projected themselves onto the world from their particular position. ${ }^{35}$

Vergès further distinguishes Creole cosmopolitanism as follows:

Originally a central concept of European philosophy, cosmopolitanism designated a universal humanism transcending regional particularism. In the colonized world of the late $20^{\text {th }}$ century, Creoles adopted that notion but creolized it: their universal humanism was informed by their opposition to racism and colonial exploitation. Their cosmopolitanism embodied a translocal experience that was a particular aspiring to the universal. Postcolonial Creoles criticized certain aspects of that universalism, arguing that nationalism was an emancipatory and potent force against colonialism. The particular could not be reduced to tradition and reaction. ${ }^{36}$

She explains how the forced nature of Creole cultures has led to a paradoxical combination of disjunction and the desire to "project oneself onto the world in order to escape the local disjunction, the lack of political horizon and the betrayal of the revolutionary promise." 37 Vergès illustrates how cosmopolitanism became the means by which Creole cultures were able to synthesize their constant fluidity and their imitation of republican — and hence colonial — ideals to manifest their new emancipation. Creole cosmopolitanism, then, is one of three "communities of recognition," the other two being local and a "culture of reaction," and that of the colonizer. For the latter, Vergès uses the

\footnotetext{
${ }^{34}$ Françoise Vergès, "Vertigo and emancipation, creole cosmopolitanism and cultural politics," Theory, Culture \& Society, 18, 2-3 (2001), 169.

${ }^{35}$ Ibid., 169. Emphasis added.

${ }^{36}$ Ibid. Emphasis added.

${ }^{37}$ Ibid., 170.
} 
example of the French republic, which "seeks political assimilation as a sign of recognition within the nation": 38

Creole cosmopolitanism represents a projection onto the world, beyond the ties of the reactive community (which protects the Creole difference) and the republican community (which does not recognize the Creole difference). Creole cosmopolitanism gives access to the universal, which localized Creole identities have seemed unable to provide. ${ }^{39}$

Vergès goes on to examine two discourses of Creole cosmopolitanism. One, which she calls "universalist cosmopolitanism," emerged in the first half of the twentieth century; the other, which she calls "revolutionary internationalism," was contemporary with the movement for decolonization in the second half of the twentieth century. In conclusion, she reflects on the actuality and relevance of Creole cosmopolitanism in the current era of globalization. Drawing upon Édouard Glissant's theory of creolization, she explains:

Glissant has argued that 'Creole' refers to a mode of cultural construction that is absolutely original. Creolization emerges from the contact of different cultures in a defined place. The result is a new emergence, but one which cannot be determined, planned or guessed at. It is entirely unpredictable. This is an important aspect of Glissant's theory: whereas the result of metissage can be foreseen, it is fundamental to understand that the result of creolization will remain unforeseen. Creolization is not multiculturalism, or simply an expression of the paradoxes of postmodern subjectivities. Creolization produces identities that are not rooted but grow as rhizomes (Glissant borrows Deleuze and Guattari's notion) and which do not seek to delimit a territory on which to express themselves. With creolization, one can envision a future in which humanity will be diverse, multiple and whose identities will be based on relation rather than on filiation, blood, ancestry, land. The cosmopolitanism that Glissant's creolization provides is in Ideal, and as an Ideal may open our mental space, expand our imagined community: the world is my territory, I am not like a tree but like a plant with multiple roots

\footnotetext{
38 Ibid.
}

39 Ibid. 
(mangrove, banyan), I conceive my encounter to the Other as a relation, not as a confrontation. ${ }^{40}$

Returning to Collen's novels, the characters and narratives that she creates in There Is a Tide and The Rape of Sita symbolize this creolization of spontaneity and unpredictability. In There Is a Tide, Shynee is not an archetypical machinist, nor does she match the stereotype of an anorexic. Rather, her refusal to eat is directly linked to both her self-analysis and her critique of Mauritius' colonial legacy. Similarly, in The Rape of Sita, Iqbal is no stereotypical narrator; on the contrary, he is androgenous and open-indeed insistent - on interruptions from his listening audience. As the novel's heroine, Sita embodies the contradictions of activisim and women's vulnerability, as she struggles to unearth her deeply suppressed memory of being raped.

Rosabelle Boswell offers a different perspective on creolization in Mauritius. She argues that the term le Malaise Créole, a phrase coined in the 1990s to describe the phenomenon of social exclusion by members of Creole society in Mauritius, is a malady not of Creole identity itself, but of the various misleading interpretations generated by outsiders and internalized by Mauritians. As she explains:

In the course of research, I discovered that it is only in seeing Mauritian society as a place of various, discursive hegemonic formations that one begins to understand the intricacies of identity formation among Creoles.... [Instead,] I suggest that Mauritians have been keen to 'make sense' of bewildering social complexities by essentializing groups and treating hybrids as aberrations that threaten social order. However, not everyone receives the impositions of powerful groups and individuals passively nor is the process facilitated by modernization and its encouragement of new freedoms. ${ }^{41}$

Boswell goes on to describe the ways in which discourse on a concept of "rootedness" is pivotal in acquiring authority, privilege, and control. Within this context, some Creoles use "le Malaise Créole" to homogenize Creole identity, in order to make participation in Mauritius' pluralistic society more effective. ${ }^{42}$ In contrast to Creole awareness and movements in the Caribbean, Mauritian Creoles were subjected to "violent domination"

\footnotetext{
${ }^{40}$ Ibid., 179. Emphasis in the original.

${ }^{41}$ Rosabelle Boswell, Le Malaise Créole: Ethnic Identity in Mauritius (New York: Berghahn Books, 2006), xx.

42 Ibid., 2.
} 
from the seventeenth to the nineteenth centuries, and then to South Africa under apartheid as a close neighbor during the twentieth century. ${ }^{43}$ With the increase of the Indian population and Indian media influence on the island, images of white superiority and corresponding marginalization of both blackness and mixed heritage persist.

At the same time, internal contradictions are present as well. Boswell notes the discussions in 2004 over the inclusion of Kreol language in the primary school curriculum. Despite the fact that Kreol is Mauritius' lingua franca, local newspapers ridiculed the proposal, and local media engaged in heated debate. Conversely, emphasizing African heritage has encountered less resistance, because it offers a way to downplay mixedness. As Boswell states, "In multicultural Mauritius, there can be no space for ambiguity." 44

In summary, Boswell argues that Creole identity is considered "a non-identity, as there is no singular homeland from which to construct an identity," and Creole is "a sort of anti-category, useful for other groups to define themselves and as a means to establish hegemony." 45 As a result, dominant groups must construct "fictions of homogeneity relating to the various groups within the hegemony. Myth, legend and history become resources that enable the crafting or maintenance of this fiction and that contested interpretations of le malaise Créole indicate varied attempts to create a particular identity for Creoles." 46 Boswell goes on to present four interpretations of le malaise Creole. First is the fragmenting and often annihilating repercussions of slavery on identity, solidarity, and economy. While useful to explain why Creoles continue to evoke an idealized essential identity as well as hybridity, this interpretation risks an overly homogeneous view of Mauritian Creole society. The second focuses on pathologies that emerge from having no identity; however, this interpretation is not useful, because it does not explain either the social pathologies themselves, or their absence among portions of Creole society. The third is derived from a primordial and evolutionist perspective that results from hybridity or African heritage. Again, this interpretation is not useful, because it denies any causal link between the legacy of slavery and le malaise Creole. Boswell thus asserts that its only value is its acknowledgment of Creole primordialist views. The fourth and final interpretation is of le malaise Créole as:

\footnotetext{
${ }^{43}$ Ibid., 5.

${ }^{44}$ Ibid., 6.

45 Ibid., 11.

46 Ibid.
} 
A construct designed to homogenize the Creole group and their experiences. I argue that dominant groups and Creoles have both fostered this concept for specific political gain. Dominant groups make reference to le malaise Créole to distinguish the ultimate 'other' and some Creoles and their advocates use it as a means to motivate for social and economic reparations. ${ }^{47}$

Thus, it is within this paradoxical framework: fragmentation within a common heritage of islands and waterways distinguished from the neighboring continents of Africa and Asia; the official languages of English for education and administration, French for literature, and Mauritian Creole as the most widely spoken; and a cultural convergence that finds some of its greatest literary expression in a French metropolitan literary medium, that Collen's work, largely written in English, has emerged and gained prominence. This has important implications for the identification of her work as postcolonial and postmodern, as well as for the association of English, primarily if not exclusively, as a language of colonizers.

\section{FEMINISM, ECOFEMINISM, AND ECOCRITICISM}

Feminism, ecofeminism, and ecocriticism have all met with various expressions of advocacy and criticism, not least of which is the assertion that these schools of thought lack focus and in some cases rigor. ${ }^{48}$ While this is also true for the theories addressed in the previous section, the overlaps between feminism and ecology have both enhanced and complicated each theoretical body in ways that defy simplification. In fact, much as

\footnotetext{
${ }^{47}$ Ibid., 12.

${ }^{48}$ The main concepts and arguments of these three theoretical bodies will not be discussed here. For an overview of principal concepts and arguments of African feminism, see: Ada Uzoamaka Azodo, African Feminism in the Global Arena: Novel perspectives on gender, class, ethnicity, and race (Milwaukee: Goldline and Jacobs Publishing, 2019); Aili Mari Tripp, "How African feminism changed the world," African Arguments, 2017: https://africanarguments.org/2017/03/how-african-feminism-changed-the-world/ [Accessed: 6 Aug. 2021]. For a brief analysis of reaction to feminism in Mauritius, see: Ariel Saramandi, “"There is too much feminism': On the rise of the Mauritian alt-right," Los Angeles Review of Books (2019). For an overview of ecofeminism, see: Laura Hobgood-Oster, "Ecofeminism: Historic and international evolution," in The Encyclopedia of Religion and Nature, ed. Bron Taylor (Oxford: Oxford University Press, 2010); Nancy Tuana and Rosemari Tong, "Anarcha feminist and ecological feminist perspectives," in Feminism and Philosophy: Essential readings in theory, reinterpretation and application, ed. Nancy Tuana (New York: Routledge 2018), 327-9. For a discussion of ecofeminism in Oceania, see: Julia I. Frengs, "Anticolonial ecofeminisms: Women's environmental literature in French-speaking Oceania," French Cultural Studies, 31, 4 (2020), 293-303. See also: Jacklyn Cock, Writing the Ancestral River: A biography of the Kowie (New York: New York University Press, 2018). For a recent study of ecocriticism, see: Matthew Schneider-Mayerson, Alexa Weik von Mossner, and W.P. Malecki, "Empirical ecocriticism: Environmental texts and empirical methods," ISLE: Interdisciplinary studies in literature and the environment, 27, 2 (2020): 327-36. See also: Paul Lindholdt, Explorations in Ecocriticism: Advocacy, bioregionalism, and visual design (Lanham: Lexington Books, 2015).
} 
Collen's novels depict the full composite of postcolonial, hybridity, creolization, and cosmopolitanism in the previous section, they also represent the full complexity of feminism, ecofeminism, and ecocriticism in a way that suggests the danger of excessive theoretical disengagement or unpacking.

Collen's work resonates with that of Canadian feminist Margaret Atwood, whose dystopian The Handmaid's Tale is echoed in There Is a Tide. Collen's activism is congruent with forms of African feminism that focus on both the value of women's contributions to the home and family and also material equity. Her range of perspectives and de-gendering of language, especially through the narrator Iqbal in The Rape of Sita, resonates with the views of Western feminists such as Hélène Cixous who call for a rejection of the very language of patriarchy. ${ }^{49}$

One may see in the extensive use of mythology in Collen's novels a rejection of an ultimate reality or truth as presented by Jacques Derrida, a major influence on Cixous. ${ }^{50}$ This in turn is congruent with the aforementioned designation of myth as a phenomenon that transcends what one traditionally has called history to reveal that all history is perspective rather than fact. The mythological traditions upon which Collen draws stem from Europe and Asia; but the setting of the novel is primarily postcolonial Mauritius. Therefore, the postcolonial relevance is transformed in a way that effectively responds to the previously noted dilemmas of postcolonial thought expressed by Hawkins, Guignery, and others regarding a seemingly infinite era of colonial aftermath, one that Arnold would identify as "post-colonial." Similarly, Collen presents rape as an ongoing egregious act of abusive patriarchal power, named in the novel's opening poem "Time" as the "eternal dilemma." 51

Moreover, this presentation of rape as a past and present leitmotif does not stop with Sita. On the contrary, the rapist Rowan Tarquin rapes his own wife Noella, but denies this, claiming, "you can't rape your own wife. She's yours." 52 Thus, the rape of Sita, as well as the rape of Noella, symbolizes rape as a myth of patriarchy which is not considered a crime, but rather a predictable manifestation of man's aggression and something that women allow and even desire. ${ }^{53}$ As Gilman explains:

\footnotetext{
${ }^{49}$ Charles E. Bressler, Literary Criticism: An introduction to theory and practice, 5th ed. (Boston: Pearson 2011): 155-6.

${ }^{50}$ Ibid., 88-90.

${ }^{51}$ Collen, The Rape of Sita, 5.

${ }^{52}$ Gilman, "AA bunch of grapes'," 101; Collen, The Rape of Sita, 66.

53 Gilman, "“A bunch of grapes,', 102-3.
} 
The Rape of Sita reaches beyond the oppression of women to encompass the oppression of all people, in all cultures. The hope lies in the idea that this recreated text will encourage further discourses that recover the voice of the 'othered' subject. At the end of the novel, Iqbal imagines a utopian vision of a coming together of the sexes in which tyrannical power relations will have come to an end. ${ }^{54}$

In this way, postcolonialism and feminism are deeply intertwined through the contemporary re-writing of an ancient myth, an act that underscores Derrida's assertion that the written word can never be fully determined by context. ${ }^{55}$ As Frenkel stresses, in Collen's novels, "physical bodies are archives of historical data." ${ }^{156}$ Frenkel focuses on the way the novel presents the context in which rape is made possible in Mauritius and elsewhere and thus negates this dimension of women's trauma, which Collen in turn connects to the Indian Ocean's trauma of colonialism. Frenkel elaborates on the liminality - anthropologically defined as the state of ambiguity that characterizes a life passage - between Sita and Iqbal. The latter tells the story, but the story actually belongs to the former, and at times to Iqbal as well. ${ }^{57}$ Through this portrayal, Collen illuminates the broader significance of the rape of Sita to be the rape of places like Mauritius at the hands of colonizers, and the rape of the earth through violence and greed. Frenkel chooses to concentrate on liminality, rather than to elaborate on the metaphor of rape for colonization, which she accurately notes has been adequately addressed in feminist literature. She explains how Collen's racial and gender ambiguities in constructing her characters present, and indeed celebrate, the complexity of Mauritian society. The enigmatic nature of Iqbal's gender removes the Linnaean logic that could otherwise obfuscate the narrative substance. As she explains:

Colonial systems of thought can clearly be characterized as a system of extremes which attempted to encode the body and social order according to its Linnaean logic. When such taxonomies are undone by the very bodies it attempted to regulate, a different conception of cultural truth emerges, as a cultural history of Indian Ocean texts illustrates. As previously discussed, as

\footnotetext{
${ }^{54}$ Ibid., 103.

${ }^{55}$ See: Eileen Williams-Wanquet, "Lindsey Collen's The Rape of Sita: Re-writing as ethics," Commonwealth Essays and Studies, 29, 2 (2007), 55-6.

${ }^{56}$ Frenkel, "A history of cultural negation," 14.

${ }^{57}$ Ibid., 13-14.
} 
we order, we necessarily disorder. And what is excluded in this process can be seen as forming a history of cultural negation that necessarily inverts the logical order when centralized, throwing up new objects of desire as it repositions the terms of discourse. And this is perhaps the intervention that this novel makes into the history of cultural negation as it centres liminality in the formation of symbolic processes. ${ }^{58}$

Frenkel further notes the liminality of Collen herself, as a white South African woman with a Mauritian Indian husband who has a history of activism as an opponent of apartheid and an advocate for women, and who has made the Indian Ocean region her home.

Eco-feminism and ecocriticism are present in the novels as well. Charles Bressler defines ecocriticism as

the study of the relationship between literature and the physical environment. Just as feminist criticism examines language and literature from a genderconscious perspective, and Marxist criticism brings an awareness of modes of production and economic class to its reading of texts, ecocriticism takes an earth-centered approach to literary studies. ${ }^{59}$

In There Is a Tide, Collen herself identifies the theme of fracture, "the fracture between the characters and the nature that we, as humans, are part of. A kind of broken ecology" as well as an ecological fracture within her characters, and a third social fracture into warring groups "those who work to live and those who control stocks derived from past work, work or not." ${ }^{\prime 60}$ Her example from There Is a Tide is the plan of the two fishermen, Gandhi and Tikay, to set fire to the cane field but be out to sea in a boat when the fire actually starts, thus preventing any chance of being accused of arson. They set fire to the cane field, because they know the boss must cut the cane quickly once it is burnt, to prevent fermentation. Tragically, the two men are not trained as fishermen, are unaccustomed to spending time on the water, and have no idea that a cyclone is imminent, one that will ultimately take their lives. Gandhi and Tikay are thus fractured from nature

\footnotetext{
58 Ibid., 15-16.

${ }^{59}$ Bressler, Literary Criticism, 234.

${ }^{60}$ Lindsey Collen, "Lindsey Collen looks at ecology in her novels," English Studies in Africa, 62, 1 (2019), 45-6. Emphasis in the original.
} 
in their inability to obtain food, from within by their inability to work holistically for food and other necessities, and socially from the exploitation of a dominating class.

Likewise, There Is a Tide exposes the deep connections between local ecologies and global economies, tracing the changing relationships at individual and collective levels. Shynee's refusal to eat is an act of resistance to rampant consumerism, not the anorexia usually documented in the fields of psychology and other medicine. Shynee's struggle is within, but is manifested on behalf of her compatriots. Her reminiscence of eating traditional Mauritian food while growing up collides with her desire for a figure like those advertised in Western media; in addition, traditional Mauritian food is by definition a blend of cuisines introduced by various colonizers over centuries. Thus, the battle is both between traditional Mauritius and Western-imposed globalization, and also within Mauritian culture itself in Shynee's psyche. ${ }^{61}$ Yet the ecological association is not completely tragic. On the contrary, the cyclone also symbolizes a much-needed societal revolution, and fortuitously Shynee's father, labor activist Larmwar, is born during the cyclone. From an ecocritical perspective, therefore, There Is a Tide (with the title itself implying a tide that signifies a dialectic between change and continuity) is firmly grounded on the ecocritical premise of total interconnectedness with the earth and the inevitable perils of separating, or to echo Collen's term, fracturing that interconnectedness.

\section{CONCLUSION}

Haring has argued:

It is because the local so loudly proclaims the political that I regard the folklore of the Southwest Indian Ocean as a symbolically central topic of study. Global processes of convergence and clash are played out in regional folklore. The multicultural history of Mauritius and the other islands demands that we reverse the politico-cultural hierarchy that has treated them as insignificant. These islands are not marginal, they are central. They are prime sources for the way the world is coming to look. The metissage we see

\footnotetext{
${ }^{61}$ See: Alexa Weik von Mossner, "Of sweatshops and cyclones: Cultural memory and postcolonial ecology in Lindsey Collen's There Is a Tide," English Studies, 91, 7 (2010), 761-75.
} 
in them becomes the central concept for a twenty-first century understanding of literary-artistic communication. ${ }^{62}$

Furthermore, "Folklorists are uniquely positioned; they direct attention to local cultural situations and they demonstrate the relevance of the local to the global."63

The preceding pages have presented two of Collen's best-known novels in the context of Mauritian language and literature. They have also presented the novels as examples of the postcolonialism, hybridization, creolization, and cosmopolitanism that characterize Mauritius in particular and the Indian Ocean region more generally. The complexity of themes and characters in There Is a Tide and The Rape of Sita epitomizes the complexity of Mauritian society and of much of the Global South. Collen's novels reveal the risk of disengaging theories of feminism, ecofeminism, and ecocriticism. These theories are complicated and overlapping, primarily because they reflect a complicated and overlapping set of realities, which Mauritius embodies.

While Lindsey Collen is not classified as folklorist per se, her extensive use of folklore, myth, and storytelling in her novels reveals the local realities of Mauritius as a microcosm of those same realities worldwide. Moreover, her presentation of these themes in the novels, There Is a Tide and The Rape of Sita, epitomizes a whole of creation that requires multiple theoretical perspectives to comprehend, through which those forming the theories may find a need to recognize and remove false dichotomies. Her choice of English is rooted in accessibility, both to publishers and to readers; those who read her work - and those whom she would argue need to read her work-are able to do so precisely because they are written in English, rather than in Mauritian Kreol, which would confine readership much more within Mauritius. Moreover, by writing in English, Collen departs from the elite association of French as the predominant literary language and corresponding Francophone literary dominance. Hence margin and center are revealed as imagined divisions, created by patriarchal assumptions about power, as well as humans' relationship to the earth, and deconstructed and transformed by narrating the human condition across gender, class, nation, and time.

\footnotetext{
${ }^{62}$ Lee Haring, "Who were you talking to? Diasporic folktales," Journal of Folklore Research, 40, 2 (2003), 149.

${ }^{63}$ Ibid., 168.
} 